\title{
PERBEDAAN KADAR KOLESTEROL TOTAL DAN TRIGLISERIDA SEBELUM DAN SETELAH PEMBERIAN SARI DAUN CINCAU HIJAU (PREMNA OBLONGIFOLIA MERR) PADA TIKUS DISLIPIDEMIA
}

\author{
Wahyu Budiyono, Aryu Candra ${ }^{*}$ \\ Program Studi Ilmu Gizi Fakultas Kedokteran Universitas Diponegoro \\ Jl.Dr.Sutomo No.14, Semarang, Telp (024) 8453708, Email : gizifk@undip.ac.id
}

\begin{abstract}
Background : Dyslipidemia is a risk factor for cardiovascular disease. High levels of cholesterol and triglycerides in the blood is closely linked to the increasing incidence of the disease. Green cincau leaves (Premna oblongifolia Merr) is a plant that contains fiber and chlorophyll potentially lower total cholesterol and triglycerides serum. Require analysis to determine differences in total cholesterol and triglycerides before and after giving of the leaf extract of green cincau leaves.

Methods : This study is a experimental labolatory with randomized control groups pre-post design. Subjects in this study were male Sprague Dawley strain rats aged 7-8 weeks induced dyslipidemia, given the green cincau leaves extract as much as 2,7 $\mathrm{ml}$ and 5,4 $\mathrm{ml}$ for 28 days. Total cholesterol and triglycerides were measured using the CHOD-PAP (Cholesterol Oxidase - Para Aminophenazone) and GPO-PAP (Glycerol Phosphate Oxidase - Para Aminophenazone). Normality of data was tested with the Shapiro Wilks, and then analyzed using paired test and analyzed using parametric statistical tests Anova and non-parametric Kruskal Wallis followed by Post Hoc analysis. Result : Giving green cincau leaves (Premna oblogifolia Merr) extract with 5,4 $\mathrm{ml}$ dose in rats can decrease triglycerides level significantly from 102,86 $\pm 20,07 \mathrm{mg} / \mathrm{dl}$ to $84,14 \pm 23,75 \mathrm{mg} / \mathrm{dl}(\mathrm{p}<0,05)$. There was an increase in total cholesterol levels significantly $(p<0,05)$ in the group by giving green grass jelly (Premna oblogifolia Merr) extract at dose of 2,7 $\mathrm{ml}$ and 5,4 $\mathrm{ml}$, increased 13,14 \pm 6,41 $\mathrm{mg} / \mathrm{dl}$ and 20,29 $\pm 10,84 \mathrm{mg} / \mathrm{dl}$ respectively.

Conclusion : Green cincau leaves (Premna oblongifolia Merr) extract 5,4 ml/day can significantly decrease triglycerides significantly in Sprague Dawley rats dyslipidemia for about $\pm 18 \%$.
\end{abstract}

Keywords : green cincau leaves; total cholesterol; triglycerides; dyslipidemia

\section{ABSTRAK}

Latar Belakang : Dislipidemia merupakan faktor risiko terjadinya penyakit kardiovaskuler. Tingginya kadar kolesterol dan trigliserida dalam darah berhubungan erat dengan meningkatnya kejadian penyakit tersebut. Cincau hijau (Premna oblongifolia Merr) merupakan tanaman yang mengandung serat dan klorofil yang berpotensi menurunkan kadar kolesterol total dan trigliserida. Perlu dilakukan analisis untuk mengetahui perbedaan kadar kolesterol total dan trigliserida sebelum dan setelah pemberian sari daun cincau hijau.

Metode : Penelitian ini adalah penelitian experimental labolatory dengan randomized control groups pre-post design. Subjek dalam penelitian ini adalah tikus jantan galur Sprague Dawley umur 7-8 minggu yang diinduksi dislipidemia, diberi sari daun cincau hijau sebanyak 2,7 ml dan 5,4 ml selama 28 hari. Kadar kolesterol total dan trigliserida diukur dengan menggunakan metode CHOD-PAP (Cholesterol Oxidase - Para Aminophenazone) dan GPO-PAP (Glycerol Phosphate Oxidase - Para Aminophenazone). Normalitas data diuji dengan Shapiro Wilks, kemudian dianalisis dengan menggunakan uji t berpasangan dan dianalisis menggunakan uji statistik parametrik Anova dan non parametrik Kruskal Wallis dilanjutkan dengan analisis Post Hoc.

Hasil : Pemberian sari daun cincau hijau (Premna oblogifolia Merr) dengan dosis 5,4 ml pada tikus mampu menurunkan kadar trigliserida secara bermakna dari 102,86+20,07 mg/dl menjadi 84,14+23,75 mg/dl (p <0,05). Terjadi peningkatan kadar kolesterol total secara bermakna $(p<0,05)$ pada kelompok dengan pemberian sari daun cincau hijau (Premna oblogifolia Merr) dengan dosis 2,7 ml dan 5,4 ml, yang masing-masing mengalami

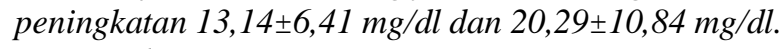

Kesimpulan : Sari daun cincau hijau 5,4 ml/hari mampu menurunkan kadar trigliserida tikus Sprague dawley dislipidemia secara bermakna $\pm 18 \%$.

Kata Kunci : cincau hijau; kolesterol total; trigliserida; dislipidemia

\section{PENDAHULUAN}

Dislipidemia merupakan keadaan yang ditandai dengan kadar kolesterol total, kolesterol
LDL ( Low Density Lipoprotein ), kolesterol HDL ( High Density Lipoporotein), dan trigliserida serum di luar batas normal. ${ }^{1}$ Dislipidemia dapat

${ }^{*}$ Penulis Penanggungjawab 
diklasifikasikan berdasarkan profil lipid yang menonjol, seperti hiperkolesterolemia, hipertrigliseridemia, rendahnya kolesterol HDL atau gabungan dari ketiganya. ${ }^{2}$

Selama ini dislipidemia menjadi faktor risiko terjadinya penyakit kardiovaskuler. Tingginya kadar kolesterol dan trigliserida dalam darah berhubungan erat dengan meningkatnya kejadian penyakit tersebut. ${ }^{1,3,4}$ Pada tahun 2005, WHO (World Health Organization) memperkirakan penyakit kardiovaskuler telah menyebabkan kematian lebih dari 18 juta jiwa di seluruh dunia dan $44 \%$ diantaranya berusia dibawah 60 tahun. $^{5}$ Di Indonesia penyakit kardiovaskuler berkontribusi sebanyak 30\% dari total kematian karena penyakit pada tahun $2008 .{ }^{6}$

Kadar kolesterol dan trigliserida dalam darah dipengaruhi oleh berbagai faktor, diantarannya umur, genetik, pola makan, obatobatan, merokok, konsumsi alkohol dan kopi, BMI (Body Mass Index), aktivitas fisik dan stress. ${ }^{7,8}, 9$ Olah raga teratur, terapi farmakologi, serta pengaturan pola makan merupakan beberapa cara untuk menurunkan kadar kolesterol dan trigliserida. $^{7,10}$ Pengaturan pola makan yang dilakukan adalah dengan membatasi sumber makanan yang tinggi lemak jenuh dan kolesterol, serta meningkatkan asupan sayur dan buah yang tinggi akan antioksidan dan serat. ${ }^{4,7,8}$

Cincau hijau (Premna oblongifolia Merr) merupakan salah satu tanaman yang mengandung serat. Masyarakat sering memanfaatkan daun cincau hijau sebagai bahan pembuat minuman agar karena kemampuannya dalam membentuk gel. Sari dari tanaman cincau hijau dapat membentuk gel karena mengandung serat larut air. Kandungan serat larut air yang dimiliki salah satunya adalah polisakarida pektin. ${ }^{11}$ Pektin termasuk jenis serat pangan yang larut air dan mudah difermentasi oleh mikroflora usus besar. ${ }^{12}$ Oleh karena kandungan pektinnya, maka cincau hijau dapat dianggap sebagai sumber serat pangan yang baik. Penelitian yang dilakukan oleh Cerda et al menyatakan bahwa serat larut air jenis pektin mampu menurunkan kadar kolesterol total dan LDL serum ${ }_{7,13}$ Penurunan kadar kolesterol dan trigliserida oleh serat dilakukan dengan cara mengikat asam lemak bebas serta kolesterol dalam bentuk asam empedu ketika dalam saluran pencernaan, kemudian mengeluarkannya melalui feses. Serat juga difermentasikan oleh mikroflora di dalam usus sehingga menghasilkan asam asetat, propionat dan butirat yang dapat menghambat sintesis kolesterol. ${ }^{11,12}$
Cincau hijau selain memiliki serat juga memiliki senyawa antioksidan salah satunya adalah klorofil. ${ }^{14,15}$ Kadar klorofil pada cincau hijau relatif tinggi yakni 1709 ppm. ${ }^{16}$ Penelitian yang pernah dilakukan pada kelinci menunjukkan bahwa ekstrak turunan klorofil mampu menekan peningkatan kadar kolesterol total dan trigliserida serum. ${ }^{17}$ Belum banyak penelitian yang memanfaatkan potensi cincau hijau khususnya dalam kondisi segar untuk memperbaiki profil lipid serum sehingga sebagai studi awal peneliti ingin meneliti perbedaan kadar kolesterol total dan trigiserida sebelum dan setelah pemberian sari daun cincau hijau pada tikus sprague dawley yang diinduksi dislipidemia. Tikus dipakai sebagai subjek dalam penelitian ini karena mempunyai sifat lebih tahan terhadap perlakuan, omnivora, tidak dapat muntah, serta asupan makan dapat dikontrol.

\section{METODE PENELITIAN}

Penelitian ini merupakan penelitian bersama dengan jenis true experimental laboratorik dengan pre and post test with randomized control group design. ${ }^{18}$ Variabel bebas penelitian ini adalah pemberian sari daun cincau hijau (Premna oblongifolia Merr) dengan dosis 2,7 ml dan 5,4 ml, sedangkan variabel terikatnya adalah perubahan kadar kolesterol total dan trigliserida. Hasil akhir yang dianalisis dalam penelitian ini adalah kadar kolesterol total dan trigliserida.

Subjek penelitian yang digunakan adalah tikus jantan galur Sprague Dawley umur 7-8 minggu yang didapatkan dari Laboratorium Farmasi Universitas Gajah Mada, Yogyakarta. Besar sampel minimal dalam penelitian ini ditentukan berdasarkan rumus Federer yaitu (t-1) (n-1) $\geq 15$, bahwa t merupakan jumlah perlakuan, sedangkan $\mathrm{n}$ merupakan banyak pengulangan pada tiap perlakuan. Bedasarkan perhitungan tersebut didapatkan besar sampel minimal untuk tiap kelompok sebanyak enam ekor. Pada penelitian ini menggunakan tujuh ekor tikus setiap kelompok untuk mengantisipasi terjadinya drop out. Pada penelitian ini terdapat empat kelompok yang terdiri dari kontrol negatif, kontrol positif, kelompok perlakuan sari daun cincau hijau $2,7 \mathrm{ml}$, dan kelompok perlakuan sari daun cincau hijau $5,4 \mathrm{ml}$ sehingga tikus yang digunakan berjumlah 28 ekor. Penentuan subjek setiap kelompok dilakukan secara simple random sampling dengan cara mengambil setiap kelipatan 4 .

Seluruh subjek diaklimatisasi dalam kandang individu dan diberi pakan standar 
sebanyak 20 gram per hari serta minum air ad libitum selama 7 hari. Pada hari ke-8 kelompok kontrol negatif diberi pakan standar sampai akhir penelitian sedangkan kelompok kontrol positif dan kelompok perlakuan diberikan pakan tinggi lemak selama 28 hari untuk membuat tikus menjadi dislipidemia. Pakan tinggi lemak dibuat dengan cara menambahkan pakan standar dengan kuning telur puyuh sebanyak $10 \%$ atau dengan perbandingan $1: 9$.

Sari daun cincau hijau yang digunakan berasal dari daun cincau hijau perdu (Premna oblongifolia Merr) yang berasal dari daerah Semarang. Dosis cincau hijau yang diberikan kepada tikus didasarkan pada penggunaan daun cincau hijau di manusia yaitu sebesar $150 \mathrm{~g}$. Dosis tersebut kemudian dikonversi dari manusia dengan berat $60 \mathrm{~kg}$ ke tikus dengan berat $200 \mathrm{~g}$ sehingga didapatkan perhitungan: $0,018 \times 150 \mathrm{~g}=2,7 \mathrm{~g}$ daun cincau hijau. ${ }^{19,20}$ Dari perhitungan tersebut didapatkan dosis kelompok perlakuan pertama sebesar 2,7 g sedangkan kelompok perlakuan kedua diberikan dua kali dosis yaitu 5,4 g. Daun cincau hijau kemudian dikonversi menjadi sari daun cincau hijau dengan cara meremas daun yang ditambah air demineralisasi dengan perbandingan 1:1 selama 3 menit kemudian diperas sampai menghasilkan sari daun cincau hijau yang setara (misalkan $100 \mathrm{~g}$ daun cincau hijau diperas dengan $100 \mathrm{ml}$ air dan harus menghasilkan $100 \mathrm{ml}$ sari daun cincau hijau). Pada akhirnya kelompok perlakuan pertama dan kedua masing-masing diberikan sari daun cincau sebanyak 2,7 $\mathrm{ml}$ dan 5,4 ml. Pembuatan sari daun cincau hijau hanya dilakukan sekali untuk seluruh sampel yang mendapat perlakuan sari daun cincau hijau. Hal ini dilakukan agar komposisi sari daun cincau hijau yang diberikan pada masing-masing subyek homogen. Sari daun cincau hijau diberikan melalui sonde.

Profil lipid awal adalah kadar profil lipid yang diukur setelah 28 hari atau tepat sehari sebelum masa perlakuan. Profil lipid akhir tikus adalah kadar profil lipid yang diukur setelah masa perlakuan. Profil lipid diukur melalui sampel darah yang diambil melalui pleksus retroorbitalis menggunakan mikrohematokrit sebanyak $\pm 2 \mathrm{ml}^{17}$ Pengukuran profil lipid pada sampel darah dilakukan di salah satu laboratorium klinik swasta di Semarang. Pengukuran kadar kolesetrol total ditentukan secara enzymatic colorimetric dengan metode CHOD-PAP (Cholesterol Oxidase - Para Aminophenazone), sedangkan kadar trigliserida serum diperiksa secara enzymatic colorimetric dengan metode GPO-PAP (Glycerol Phosphate Oxidase - Para Aminophenazone).

Data yang diperoleh diuji normalitasnya dengan uji Saphiro Wilk. Perbedaan kadar kolesterol total dan trigliserida sebelum dan sesudah perlakuan dianalisis menggunakan uji statistik parametrik paired t-test. Apabila data berdisribusi normal dan varian data sama $(p>0,05)$ maka perbedaan antar keempat kelompok dianalisis menggunakan uji statistik parametrik Anova, sebaliknya bila distribuisi data tidak normal atau varian data berbeda $(p<0,05)$ maka perbedaan antar keempat kelompok dianalisis menggunakan uji statistik non parametrik Kruskal Wallis. Apabila didapatkan perbedaan antar keempat kelompok yang signifikan $(p<0,05)$ maka dilanjutkan dengan analisis Post Hoc.

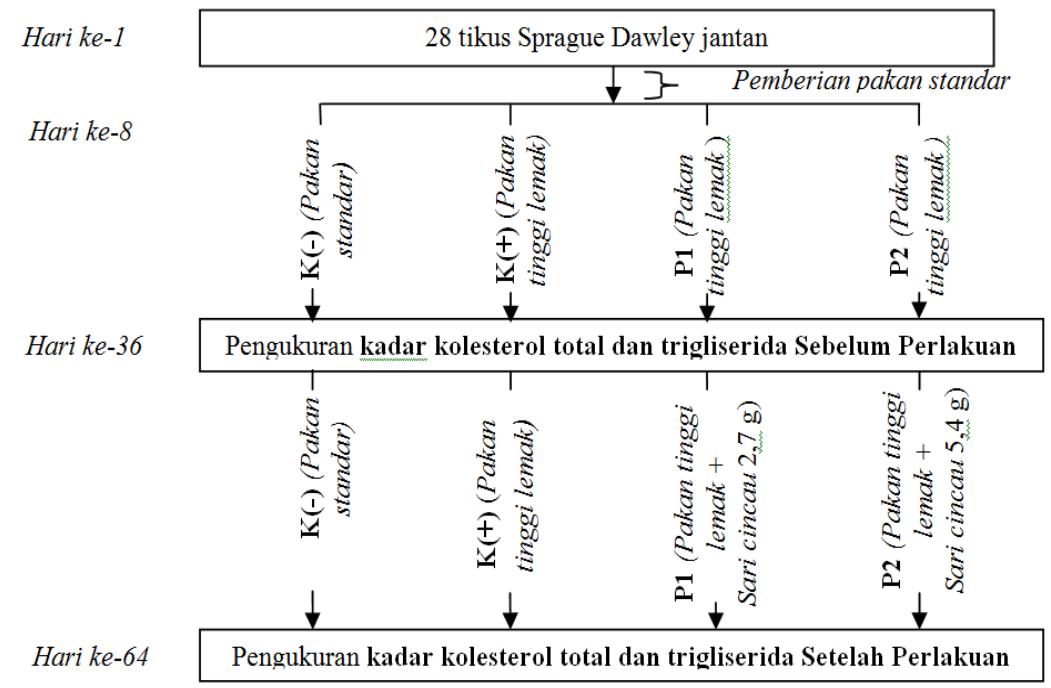

Gambar 1. Alur Penelitian 


\section{HASIL PENELITIAN}

Karakteristik Subjek

Penelitian dilakukan pada 28 ekor tikus Sprague Dawley jantan yang dipelihara dalam kandang individu dengan suhu ruangan berkisar antara $28-32^{\circ} \mathrm{C}$ dan siklus pencahayaan 12 jam.
Pembersihan kandang dan pemeliharaan dilakukan setiap hari oleh peneliti dan penjaga laboratorium.

Penimbangan berat badan dan sisa pakan dilakukan setiap hari selama penelitian berlangsung. Gambaran rerata berat badan ditunjukkan pada gambar 2 berikut.

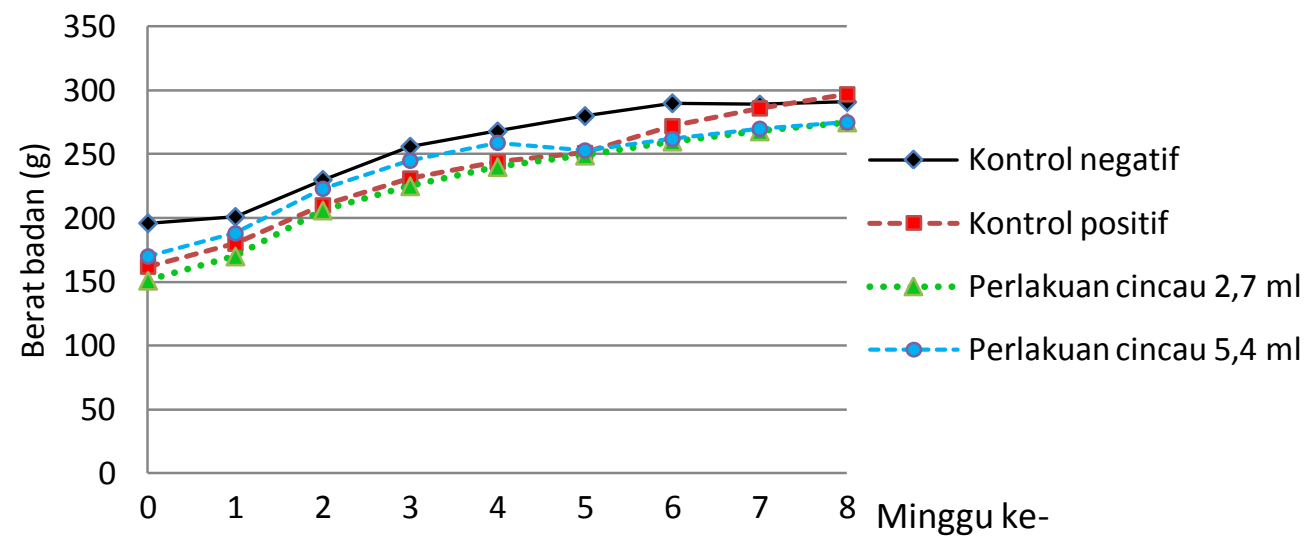

Gambar 2. Grafik Berat Badan

Gambar 2 menunjukkan bahwa rerata berat badan subjek keempat kelompok memiliki kecenderungan meningkat dari awal hingga akhir intervensi. Hal tersebut berbanding lurus dengan asupan makanan yang mengalami peningkatan seperti yang ditunjukkan pada Tabel 1 berikut.

Tabel 1. Hasil Analisis Bivariat Rerata Asupan Makanan

\begin{tabular}{|c|c|c|c|c|}
\hline \multirow[b]{2}{*}{ Kelompok } & \multirow[b]{2}{*}{$\mathbf{N}$} & \multirow{2}{*}{$\begin{array}{c}\text { Sebelum Perlakuan } \\
\begin{array}{c}\text { Rerata }(\mathrm{SB}) \\
\text { (g) }\end{array} \\
\end{array}$} & \multirow{2}{*}{$\begin{array}{c}\text { Selama Perlakuan } \\
\text { Rerata (SB) } \\
(\mathrm{g})\end{array}$} & \multirow[b]{2}{*}{$P$} \\
\hline & & & & \\
\hline $\mathrm{K}(-)$ & 7 & $16,7 \pm 0,95^{\mathrm{a}}$ & $19,1 \pm 0,38^{\mathrm{a}}$ & $0,016^{*}$ \\
\hline $\mathrm{K}(+)$ & 7 & $14,9 \pm 1,77^{\mathrm{a}}$ & $18,6 \pm 1,81^{\mathrm{a}}$ & $0,027 *$ \\
\hline $\mathrm{P} 1$ & 7 & $15,1 \pm 0,40^{\mathrm{a}}$ & $17,0 \pm 2,00^{\mathrm{a}}$ & $0,026^{*}$ \\
\hline P2 & 7 & $15,9 \pm 1,21^{\mathrm{a}}$ & $17,0 \pm 1,15^{\mathrm{a}}$ & 0,054 \\
\hline
\end{tabular}

aji Kruskal Wallis sebelum perlakuan $(p>0.05) \&$ selama perlakuan $(p<0.05)$

*beda bermakna

Keterangan : Sebelum Perlakuan : sebelum intervensi cincau

Selama Perlakuan : selama intervensi cincau

$\mathrm{K}(-)$ : kelompok kontrol negatif

$\mathrm{K}(+)$ :kelompok kontrol positif

P1 : kelompok perlakuan sari daun cincau hijau 2,7 ml

P2 : kelompok perlakuan sari daun cincau hijau 5,4 ml

Tabel 1 menunjukkan rerata asupan makan sampel sebelum dan selama perlakuan. Sebelum perlakuan, rerata asupan makan antar kelompok tidak memiliki perbedaan yang bermakna $(p>0,05)$. Selama perlakuan terdapat perbedaan rerata asupan makan antar kelompok yang bermakna yaitu antara kelompok K(-) dengan kelompok P1 $(p<0,05)$. Pada kelompok P2 tidak mengalami peningkatan rerata asupan makan bermakna $(p>0,05)$, sedangkan ketiga kelompok lainnya mengalami peningkatan rerata asupan makan yang bermakna $(p<0,05)$. 
Tabel 2. Hasil Analisis Bivariat Kadar Kolesterol Total

\begin{tabular}{|c|c|c|c|c|}
\hline & & Sebelum Perlakuan & Setelah Perlakuan & \\
\hline Kelompok & $\mathbf{N}$ & $\begin{array}{c}\text { Rerata (SB) } \\
(\mathrm{mg} / \mathrm{dl})\end{array}$ & $\begin{array}{c}\text { Rerata (SB) } \\
(\mathrm{mg} / \mathrm{dl})\end{array}$ & $P$ \\
\hline $\mathrm{K}(-)$ & 7 & $66,43 \pm 13,44^{\mathrm{a}}$ & $78,71 \pm 14,37$ & $0,009 *$ \\
\hline $\mathrm{K}(+)$ & 7 & $67,43 \pm 12,67^{\mathrm{a}}$ & $82,71 \pm 19,21$ & 0,075 \\
\hline $\mathrm{P} 1$ & 7 & $58,14 \pm 9,86^{\mathrm{a}}$ & $71,29 \pm 10,39$ & $0,002 *$ \\
\hline P2 & 7 & $56,57 \pm 10,00^{\mathrm{a}}$ & $76,86 \pm 11,31$ & $0,002 *$ \\
\hline
\end{tabular}

auji beda Anova (p>0,05)

*beda bermakna

Tabel 2 menunjukkan bahwa kadar kolesterol total sebelum perlakuan antar kelompok tidak memiliki perbedaan yang bermakna $(p>0,05)$. Kadar kolesterol total seluruh kelompok mengalami peningkatan. Pada kelompok $\mathrm{K}(+)$

mengalami peningkatan kadar kolesterol total yang tidak bermakna $(p>0,05)$, sedangkan ketiga kelompok lainnya mengalami peningkatan kadar kolesterol total yang bermakna $(p<0,05)$.

Tabel 3. Hasil Analisis Bivariat Kadar Trigliserida

\begin{tabular}{|c|c|c|c|c|}
\hline \multirow{2}{*}{ Kelompok } & \multirow[b]{2}{*}{$\mathbf{N}$} & \multirow{2}{*}{$\begin{array}{c}\text { Sebelum Perlakuan } \\
\text { Rerata }(\text { SB }) \\
(\mathbf{m g} / \mathbf{d l})\end{array}$} & \multirow{2}{*}{$\begin{array}{c}\text { Setelah Perlakuan } \\
\text { Rerata }(\mathbf{S B}) \\
(\mathrm{mg} / \mathrm{dl})\end{array}$} & \multirow[b]{2}{*}{$\boldsymbol{P}$} \\
\hline & & & & \\
\hline $\mathrm{K}(-)$ & 7 & $83,57 \pm 15,56^{\mathrm{a}}$ & $37,57 \pm 11,00$ & $0,002 *$ \\
\hline $\mathrm{K}(+)$ & 7 & $116,86 \pm 23,80^{\mathrm{a}}$ & $90,57 \pm 24,03$ & 0,130 \\
\hline P1 & 7 & $95,14 \pm 15,70^{\mathrm{a}}$ & $73,86 \pm 25,98$ & 0,086 \\
\hline P2 & 7 & $102,86 \pm 28,07^{\mathrm{a}}$ & $84,14 \pm 23,75$ & $0,033^{*}$ \\
\hline
\end{tabular}

ajui beda Anova ( $>>0,05)$

*beda bermakna

Tabel 3 menunjukkan bahwa tidak terdapat perbedaan yang bermakna terhadap kadar trigliserida sebelum perlakuan antar keempat kelompok. Kadar trigliserida pada seluruh kelompok mengalami penurunan setelah masa perlakuan. Diketahui bahwa penurunan bermakna $(p<0,05)$ antara kadar trigliserida sebelum dan setelah perlakuan terjadi pada kelompok $\mathrm{K}(-)$, sedangkan pada kelompok $\mathrm{K}(+)$ mengalami penurunan kadar trigliserida yang tidak bermakna. Pada kelompok yang diberi sari daun cincau, hanya kelompok P2 yang mempunyai penurunan kadar trigliserida bermakna $(p<0,05)$ sedangkan pada kelompok P1 tidak $(p>0,05)$.

Analisis Perubahan Kadar Kolesterol Total dan Trigliserida

Tabel 4. Hasil Analisis Perubahan Kadar Kolesterol Total

\begin{tabular}{cccc}
\hline & & $\Delta$ Kolesterol Total & \multirow{2}{*}{$\begin{array}{c}\text { Rerata }(\mathbf{S B}) \\
(\mathbf{m g} / \mathbf{d l})\end{array}$} \\
\cline { 3 - 3 } Kelompok & $\mathbf{N}$ & $12,29 \pm 8,50$ & \\
$\mathrm{~K}(-)$ & 7 & $15,29 \pm 18,77$ & 0,605 \\
$\mathrm{~K}(+)$ & 7 & $13,14 \pm 6,41$ & \\
$\mathrm{P} 1$ & 7 & $20,29 \pm 10,84$ & \\
$\mathrm{P} 2$ & 7 & & \\
\hline
\end{tabular}

Tabel 4 menunjukkan perubahan kadar kolesterol total dari sebelum hingga sesudah perlakuan. Hasil uji beda rerata antar kelompok menunjukkan tidak terdapat perbedaan kadar kolesterol total yang bermakna antar kelompok perlakuan $(p>0,05)$. 
Tabel 5. Hasil Analisis Perubahan Kadar Trigliserida

\begin{tabular}{|c|c|c|c|}
\hline Kelompok & $\mathbf{N}$ & $\begin{array}{c}\Delta \text { Trigliserida } \\
\text { Rerata }(\mathbf{S B}) \\
(\mathbf{m g} / \mathrm{dl})\end{array}$ & $P$ \\
\hline $\mathrm{K}(-)$ & 7 & $-46,00 \pm 22,91$ & \multirow{4}{*}{0,136} \\
\hline $\mathrm{K}(+)$ & 7 & $-26,29 \pm 39,61$ & \\
\hline $\mathrm{P} 1$ & 7 & $-21,29 \pm 27,46$ & \\
\hline $\mathrm{P} 2$ & 7 & $-18,71 \pm 17,97$ & \\
\hline
\end{tabular}

Tabel 5 menunjukkan perubahan kadar trigliserida dari sebelum hingga sesudah perlakuan. Hasil uji beda rerata antar kelompok menunjukkan bahwa tidak terdapat perbedaan rerata kadar trigliserida yang bermakna antar kelompok perlakuan $(p>0,05)$.

\section{PEMBAHASAN}

\section{Karakteristik Subjek}

Grafik berat badan (Gambar 2) mengambarkan bahwa selama penelitian berat badan subjek di setiap kelompok mengalami peningkatan. Hal tersebut sejalan dengan rerata asupan makan yang meningkat. Tabel 1 menunjukkan bahwa rerata asupan makan antar kelompok sebelum perlakuan tidak memiliki perbedaan yang bermakna $(p>0,05)$. Pada masa perlakuan terdapat perbedaan rerata asupan makan yang bermakna antara kelompok kontrol negatif dengan kelompok yang diberi perlakuan sari daun cincau hijau 2,7 ml dan 5,4 ml ( $p<0,05)$. Kelompok perlakuan sari daun cincau hijau 2,7 dan $5,4 \mathrm{ml}$ memiliki rerata asupan makan yang lebih rendah dibandingkan kelompok kontrol negatif dan positif. Hal tersebut disebabkan karena kelompok perlakuan sari daun cincau hijau 2,7 $\mathrm{ml}$ dan 5,4 ml mendapat asupan tambahan yakni sonde sari daun cincau hijau yang membuat kapasitas lambung subyek menjadi terbatas untuk mengkonsumsi makanan lain. Rerata asupan makan semua kelompok dari sebelum hingga selama masa perlakuan terlihat mengalami peningkatan dan hanya kelompok perlakuan sari daun cincau hijau $5,4 \mathrm{ml}$ yang mengalami peningkatan asupan makan yang tidak bermakna $(p>0,05)$. Hal tersebut bisa disebabkan karena kelompok perlakuan sari daun cincau hijau 5,4 ml mendapat asupan tambahan paling banyak yaitu sonde sari daun cincau $5,4 \mathrm{ml}$ yang mana membuat kapasitas lambung subyek menjadi paling terbatas di antara kelompok lain.

\section{Pakan Tinggi Kolesterol dan Lemak}

Pada penelitian ini tikus diinduksi dislipidemia dengan menggunakan pakan tinggi kolesterol dan lemak, yaitu pakan yang terdiri dari pakan standar ditambahkan kuning telur puyuh $10 \%$. Kuning telur puyuh dipilih sebagai campuran pakan karena memiliki kandungan kolesterol yang tinggi dibandingkan dengan kuning telur lain yaitu $2.139,17 \mathrm{mg} / 100$ gram. ${ }^{21}$ Untuk mengetahui bahwa subyek telah mengalami dislipidemia, kadar kolesterol total dan trigliserida kelompok yang mendapat pakan tinggi kolesterol dan lemak (kontrol positif, perlakuan sari daun cincau hijau 2,7 dan 5,4 ml) dibandingkan dengan kadar kolesterol total dan trigliserida kelompok kontrol negatif yang hanya mendapat pakan standar. Fungsi kelompok kontrol negatif adalah sebagai gambaran kadar kolesterol total dan trigliserida tikus normal.

Kadar kolesterol total antar kelompok setelah pemberian pakan tinggi lemak menunjukkan bahwa kelompok kontrol positif memiliki kadar yang paling tinggi dibandingkan dengan kelompok lain, meskipun hasil analisis beda rerata menunjukkan bahwa tidak terdapat perbedaan kolesterol total yang bermakna antara seluruh kelompok yang mendapat pakan tinggi kolesterol dengan kelompok kontrol negatif $(p>0,05)$.

Tabel 3 menunjukkan bahwa kadar trigliserida awal kelompok kontrol positif, perlakuan sari daun cincau 2,7 $\mathrm{ml}$ dan 5,7 $\mathrm{ml}$ lebih tinggi dibandingkan kadar trigliserida kelompok kontrol negatif, meskipun demikian hasil analisis beda rerata menunjukkan bahwa tidak terdapat perbedaan trigliserida yang bermakna antara seluruh kelompok yang mendapat pakan tinggi kolesterol dan lemak dengan kelompok kontrol negatif $(p>0,05)$.

Perbedaan kolesterol total dan trigileserida yang tidak bermakna antara kelompok yang mendapatkan pakan standar $(\mathrm{K}(-))$ dan kelompok yang mendapat pakan tinggi kolesterol dan lemak $(\mathrm{K}(+), \mathrm{P} 1, \mathrm{P} 2)$ disebabkan karena tidak dilakukan uji kandungan kolesterol \& trigliserida pada pakan standar dan pakan tinggi kolesterol \& trigliserida sehingga dimungkinkan pakan standar memiliki kandungan kolesterol dan trigliserida yang lebih 
tinggi dibandingkan pakan untuk menginduksi dislipidemia. Kemungkinan sampel memiliki kadar kolesterol total dan trigliserida yang kurang homogen sebelum induksi dislipidemia, usia dan berat badan tikus selama penelitian juga dapat menjadi penyebab lain.

\section{Pengaruh Sari Daun Cincau Hijau terhadap} Kadar Kolesterol Total

Hasil analisis bivariat menunjukkan kadar kolesterol total pada seluruh kelompok sebelum dan setelah intervensi juga mengalami peningkatan. Pada kelompok $\mathrm{K}(-)$ peningkatan kadar kolesterol total dipengaruhi oleh bertambahnya umur dan berat badan sampel serta kemungkinan pakan standar yang memiliki kandungan kolesterol yang tinggi, sedangkan pada kelompok $\mathrm{K}(+)$ peningkatan kadar kolesterol total disebabkan bertambahnya umur dan berat badan serta dipengaruhi oleh asupan makanan tinggi kolesterol dan lemak yang dikonsumsi. Pada kelompok perlakuan sari cincau hijau (P1\&P2) peningkatan kadar kolesterol total disebabkan karena asupan makanan tinggi kolesterol yang dikonsumsi dan tingkat stres yang lebih tinggi akibat penggunaan sonde. Tingkat stres yang tinggi dapat meningkatkan pelepasan kortikosteroid sehingga dapat memicu kenaikan kadar insulin serta memicu sintesis trigliserida dan sekresi VLDL oleh hati. ${ }^{22,23}$ Hal tersebut dimungkinkan menyebabkan peran sari daun cincau dalam menurunkan kadar kolesterol total menjadi kurang efektif.

\section{Pengaruh Sari Daun Cincau Hijau terhadap} Kadar Trigliserida

Kadar trigliserida pada seluruh kelompok dalam penelitian ini mengalami penurunan, tetapi penurunan trigliserida pada kelompok $\mathrm{K}(-)$ \& $\mathrm{K}(+)$ lebih besar jika dibandingkan kedua kelompok perlakuan (P1\&P2). Penurunan kadar trigliserida pada kelompok $\mathrm{K}(-)$ diduga diakibatkan oleh rendahnya tingkat stres karena tidak dilakukan sonde dan selama penelitian kelompok tersebut hanya mendapat pakan standar. Penurunan kadar trigliserida pada kelompok $\mathrm{K}(+)$ dapat dipengaruhi oleh rendahnya tingkat stres pada kelompok tersebut karena subjek pada kelompok $\mathrm{K}(+)$ hanya diberi pakan tinggi kolesterol dan tidak disonde. Penyondean dapat memicu stres pada hewan coba. ${ }^{23}$ Tingkat stres yang rendah dapat mencegah peningkatan pelepasan kortikosteroid sehingga menghambat kenaikan kadar insulin serta mampu menekan sintesis trigliserida dan sekresi VLDL oleh hati. Penurunan kadar insulin yang diikuti dengan meningkatnya sensitivitas insulin dapat meningkatkan aktivitas lipoprotein lipase sehingga mampu menurunkan kadar trigliserida. ${ }^{22,23}$

Kadar trigliserida pada kedua kelompok perlakuan (P1\&P2) mengalami penurunan walaupun hanya kelompok perlakuan sari cincau hijau 5,4 $\mathrm{ml}$ (P1) yang mengalami penurunan bermakna $(p>0,05)$. Penurunan tersebut dipengaruhi oleh serat dan klorofil yang terkandung dalam sari daun cincau hijau. Cincau hijau mengandung serat larut air yang dapat mengikat asam lemak bebas ketika masih dalam saluran pencernaan, kemudian mengeluarkannya melaui feses. ${ }^{11,12}$ Cincau hijau juga mengandung klorofil yang merupakan salah satu antioksidan yang dapat menghambat proses oksidasi lipid. ${ }^{14,15}$ Terhambatnya proses oksidasi lipid mengakibatkan terhambatnya proses pembentukan asetil Ko-A yang berperan dalam biosintesis trigliserida sehingga trigliserida yang ditransfer ke serum akan menurun. ${ }^{22,24}$ Klorofil juga diduga mempengaruhi peningkatan enzim lipoprotein lipase yang dapat berdampak pada metabolisme lipoprotein yang kaya trigliserida. ${ }^{25}$

\section{KETERBATASAN PENELITIAN}

Pada penelitian ini terdapat beberapa keterbatasan penelitian, yaitu tidak dilakukan uji kandungan kolesterol dan trigliserida pada pakan standar dan pakan tinggi kolesterol \& lemak. Keterbatasan yang lain adalah tidak dilakukan uji kadar kolesterol total dan trigliserida pada tikus sebelum dilakukan induksi dislipidemia. Selain itu juga tidak dilakukan uji kandungan serat pangan (larut air maupun tidak larut air) pada sari daun cincau hijau (Premna oblongifolia Merr). Kelompok kontrol negatif dan kontrol positif tidak diberi perlakuan sonde sehingga tingkat stres antar kelompok dimungkinkan berbeda.

\section{SIMPULAN}

Kadar kolesterol total dan trigliserida yang antar kelompok perlakuan tidak didapatkan perbedaan yang bermakna $(p>0,05)$. Terjadi peningkatan kadar kolesterol total secara bermakna $(p<0,05)$ pada kelompok dengan pemberian sari daun cincau hijau (Premna oblogifolia Merr) dengan dosis 2,7 $\mathrm{ml}$ dan 5,4 $\mathrm{ml}$. Pemberian sari daun cincau hijau (Premna oblogifolia Merr) dengan dosis 5,4 ml pada tikus mampu menurunkan kadar trigliserida tikus secara bermakna $(p<0,05)$ atau terjadi penurunan $\pm 18 \%$. 


\section{SARAN}

Pada penelitian selanjutnya perlu dilakukan uji kandungan serat pangan (larut air maupun tidak larut air) pada sari daun cincau hijau (Premna oblongifolia Merr) serta uji kandungan kolesterol dan trigliserida pada pakan standar dan pakan tinggi lemak supaya dalam penentuan dosis pemberian dapat lebih optimal. Perlu dilakukan uji kadar kolesterol total dan trigliserida pada tikus sebelum dilakukan induksi dislipidemia, supaya subjek yang memiliki perbedaan mencolok dapat di eksklusi. Pada kelompok kontrol perlu diberi perlakuan sonde air putih untuk menyamakan tingkat stres antar kelompok.

\section{DAFTAR PUSTAKA}

1. Gandy JW, Madden A, Holdsworth M, editors. Oxford Handbook of Nutrition and Dietetics. New York : Oxford University press, 2006.

2. Sudoyo AW, Setiyohadi B, Alwim I. Buku Ajar Ilmu Penyakit dalam Jilid III Edisi IV. JakartaPusat: Penerbitan Departemen Ilmu Penyakit Dalam FKUI, 2006.

3. Thompson G, Morrell J, Wilson P. Dyslipidemia in Clinical Practice 2nd ed. UK: Informa Healthcare, 2006.

4. Mittal S. Choronary Heart Disaese in Clinical Practice. US: Springer, 2007.

5. World Health Organization. High Total Serum Cholesterol, Medication Coverage and Therapeutic Control: an Analysis of National Health Examination Survey Data from Eight Countries. Bulletin of the World Health Organization, 2011; 89:92-101. Available from: http//www.who.int /entity/bulletin/.../index.html

6. World Health Organization. Noncommunicable Diseases Country Profiles 2011. Available from: http://www.un.org/en/ga/ncdmeeting2011/pdf/ncd_ profiles_report.pdf

7. Mahan LK, Escott-Stump S. Krause's Food, Nutrition, \& Diet Theraphy 11th ed. USA: Elsevier, 2004.

8. Truswell AS. Cholesterol and Byond. The Reseach on Diet and Choronary Heart Disease 1900-2000. US: Springer, 2010.

9. Departement of Health and Human Services (U.S). National Cholesterol Education Program. USA: NIH Publication, 2005. Available from: http://www.nhlbi.nih.gov/health/public/heart/chol/w yntk.pdf

10. Gunawan SG, editor. Farmakologi dan Terapi Edisi 5. Jakarta: Departemen Farmakologi dan Terapeutik FK UI, 2007.

11. Nurdin SU, Zuidar, Suharyono. Dried extract from green cincau leaves as potential fibre sources for food enrichment. African Crop Science Conference Procceding, 2005; vol. 7: 655-658

12. Gallaher D. Dietary Fiber and Its Physiological
Effect In Essential of Functional Food. Schmidl, M.K, T.P. (Eds). Maryland: An Aspen Publication, 2000.

13. Spears GE, editor. Dietary Reference Intakes for Energy, Carbohydrate, Fiber, Fat, Fatty Acids, Cholesterol, Protein, and Amino Acids (Macronutrients). Institute of Medicine (U.S). Washington: National Academies Press, 2005. Available from: http://www.nap.edu/catalog/ 10490.html

14. Hariana A. Cincau Rambat: Tanaman Obat \& Khasiatnya Seri 1. Bandung, 2004.

15. Lanfer MUM, Barros RMC, Sinnecker P. Antioxidant Activity of Chlorophylls and Their Derivatives. Food Research International, 2005: 38 (8/9) : 885-891.

16. Kusharto CM, Tanziha I, Junuwati M. Produk Ekstrak Klorofil dari Berbagai daun Tanaman Untuk Meningkatkan Respon Imun dan Aplikasinya sebagai Anti-Aterosklerosis. Laporan Penelitian LPPM IPB. Bogor, 2008.

17. Nurdin, Khomsan A, Marliyati SA, dkk. Pengaruh Pemberian Bubuk Ekstrak Cu-Turunan Klorofil daun Cincau Hijau (Premna oblongifolia Merr.) Terhadap Profil Lipid Darah Kelinci. PS. Pendidikan Kimia, FPIK, Univ. Tadulako, Palu. Media Gizi \& Keluarga, Juli 2008, 32 (1) : 104-114.

18. Hidayat, Alimul A. Metode Penelitian Kesehatan. Surabaya: Health Books Publishing, 2010.

19. Djam'an Q. The Effect of Cincau Hijau Leaves Aqueous on Acetylsalicylic acid-Induced Gastric Acid and Gastrohistopathology Feature in Rats [tesis]. Diponegoro University Institutional Repository, 2008. Available from: www.eprints.undip.ac.id/17901/1/Qathrunnada_ Djam'an. pdf

20. Ngatijan. Metode Laboratorium Dalam Toksikologi. Bagian Farmakologi dan Toksikologi Fakultas Kedokteran UGM. Yogyakarta, 2006.

21. Dwiloka B. Efek Kolesterolemik berbagai Telur. Media Gizi \& Keluarga, Desember 2003: 27(2): 5865

22. Botham KM, Mayes PA. Metabolisme asilgliserol dan sfingolipid. In: Murray RK, Granner DK, Rodwell VW, editors. Biokimia Harper. 27th ed. Jakarta: Penerbit Buku Kedokteran EGC, 2006; 217237, 239-249.

23. Balcombe JP, Barnard ND, Sandusky C. Laboratory Routine Cause Animal Stress. American Association for Laboratory Animal Science, 2004; 43(6): 42-49.

24. Mahan LK, Escott-stump S, editors. Krause`s Food, Nutrition, and Diet Therapy. 12th ed. USA: Saunders, 2008; 834-860.

25. Jensen GS, Ginsberg, C. Drapeau. Blue-Green Algae as an Immuno-Enchancer an Biomodulator. JANA, 2001; 3(4): 24-30. 